\title{
Nitrate and sulfate: Effective alternative hydrogen sinks for mitigation of ruminal methane production in sheep
}

\author{
S. M. van Zijderveld, ${ }^{\star 1}$ W. J. J. Gerrits, † J. A. Apajalahti,ł J. R. Newbold, ${ }^{\star}$ J. Dijkstra,† R. A. Leng,§ \\ and H. B. Perdok* \\ *Provimi Holding B.V., Research Centre De Viersprong, Veilingweg 23, NL-5334LD, Velddriel, the Netherlands \\ †Animal Nutrition Group, Wageningen University, PO Box 338, 6700 AH Wageningen, the Netherlands \\ $\ddagger$ Alimetrics, Koskelontie 19B, FI-02920 Espoo, Finland \\ §University of New England, Armidale, New South Wales, Australia
}

\begin{abstract}
Twenty male crossbred Texel lambs were used in a $2 \times 2$ factorial design experiment to assess the effect of dietary addition of nitrate $(2.6 \%$ of dry matter $)$ and sulfate $(2.6 \%$ of dry matter) on enteric methane emissions, rumen volatile fatty acid concentrations, rumen microbial composition, and the occurrence of methemoglobinemia. Lambs were gradually introduced to nitrate and sulfate in a corn silage-based diet over a period of $4 \mathrm{wk}$, and methane production was subsequently determined in respiration chambers. Diets were given at $95 \%$ of the lowest ad libitum intake observed within one block in the week before methane yield was measured to ensure equal feed intake of animals between treatments. All diets were formulated to be isonitrogenous. Methane production decreased with both supplements (nitrate: $-32 \%$, sulfate: $-16 \%$, and nitrate + sulfate: $-47 \%$ relative to control). The decrease in methane production due to nitrate feeding was most pronounced in the period immediately after feeding, whereas the decrease in methane yield due to sulfate feeding was observed during the entire day. Methane-suppressing effects of nitrate and sulfate were independent and additive. The highest methemoglobin value observed in the blood of the nitrate-fed animals was $7 \%$ of hemoglobin. When nitrate was fed in combination with sulfate, methemoglobin remained below the detection limit of $2 \%$ of hemoglobin. Dietary nitrate decreased heat production $(-7 \%)$, whereas supplementation with sulfate increased heat production $(+3 \%)$. Feeding nitrate or sulfate had no effects on volatile fatty acid concentrations in rumen fluid samples taken $24 \mathrm{~h}$ after feeding, except for the molar proportion of branched-chain volatile fatty acids, which was higher when sulfate was fed and lower when nitrate was fed, but not different when both products were included in the diet. The total number of rumen
\end{abstract}

Received March 22, 2010.

Accepted September 7, 2010.

${ }^{1}$ Corresponding author: svanzijderveld@nl.provimi.com bacteria increased as a result of sulfate inclusion in the diet. The number of methanogens was reduced when nitrate was fed. Enhanced levels of sulfate in the diet increased the number of sulfate-reducing bacteria. The number of protozoa was not affected by nitrate or sulfate addition. Supplementation of a diet with nitrate and sulfate is an effective means for mitigating enteric methane emissions from sheep.

Key words: hydrogen sink, methane, nitrate, sulfate, sheep

\section{INTRODUCTION}

Rumen fermentation results in the production of excess hydrogen, which needs to be removed from the rumen for the fermentation process and microbial growth to continue efficiently (Immig, 1996). In general, hydrogen is removed through the activity of methanogenic Archaea, which reduce carbon dioxide with hydrogen to generate methane and water. For most feeds consumed by ruminants, methanogenesis is the main route of hydrogen disposal during anaerobic rumen fermentation (Beauchemin et al., 2008). The methane resulting from methanogenesis represents a loss of dietary energy to the animal (Johnson and Johnson, 1995) and it is a significant greenhouse gas (Steinfeld et al., 2006). These factors have led to a global search for nutritional strategies to mitigate methane emission from ruminants.

One strategy is to redirect hydrogen into processes that yield beneficial products for the ruminant. Examples include the stimulation of propionogenesis by addition of substrates to the diet that support propionate production and attempts to introduce bacteria expressing reductive acetogenesis into the rumen (Joblin, 1999; Molano et al., 2008). These processes would yield propionate or acetate, respectively, as nutrients for the animal and at the same time would lower the hydrogen availability for methanogenesis. However, the introduction of propionate precursors (i.e., malate and fumarate) in ruminant diets has resulted in variable effects on methane production (Beauchemin and McGinn, 
2006; Wallace et al., 2006; Foley et al., 2009), and attempts to establish acetogenic bacteria in the rumen have failed because of a lower affinity of the acetogenic bacteria for $\mathrm{H}_{2}$ compared with methanogenic Archaea (Le Van et al., 1998; Ellis et al., 2008).

The possibility of nitrate as an alternative hydrogen sink to carbon dioxide has been downplayed because of the possible toxic effects of nitrite, which is formed as an intermediate during the reduction of nitrate to ammonia (Lewis, 1951). A few reports have examined the potential of nitrate as a methane-lowering feed additive, and it appears to lower methanogenesis consistently. However, lowered methane yields were found in vitro (Allison and Reddy, 1984; Guo et al., 2009) and in vivo in animals where the nitrate was dosed once daily directly into the rumen (Takahashi et al., 1998; Sar et al., 2004). Studies of effects of feeding a nitrate source on methane production appear to be lacking.

The reduction of nitrate to nitrite (Gibbs free energy, $\boldsymbol{\Delta} \mathbf{G}_{\mathbf{0}}=-130 \mathrm{~kJ} / \mathrm{mol}$ of hydrogen; Ungerfeld and Kohn, 2006) and the subsequent reduction of nitrite to ammonia $\left(\Delta \mathrm{G}_{0}=-124 \mathrm{~kJ} / \mathrm{mol}\right.$ of hydrogen; Ungerfeld and Kohn, 2006) yield more energy than the reduction of carbon dioxide to methane $\left(\Delta \mathrm{G}_{0}=-16.9 \mathrm{~kJ} / \mathrm{mol}\right.$ of hydrogen; Ungerfeld and Kohn, 2006). These processes could be the principal route of hydrogen disposal if sufficient nitrate is available in an actively fermenting rumen ecosystem. The reduction of nitrate to ammonia consumes 8 electrons and each mole of nitrate reduced could thus lower methane production by 1 mole. The ammonia generated will be available for anabolism and would be an important supply of fermentable $\mathrm{N}$ on diets deficient in $\mathrm{CP}$ where low rumen ammonia may limit microbial protein synthesis (Dijkstra et al., 1998, Leng and Nolan, 1984).

In animals unadapted to nitrate in their diet, the capacity of the rumen microflora to reduce nitrate to nitrite exceeds the capacity for nitrite reduction (Lewis, 1951). This leads to accumulation of nitrite in the rumen, which is readily absorbed across the rumen wall and converts blood hemoglobin $(\mathbf{H b})$ from the ferrous $\left(\mathrm{Fe}^{2+}\right)$ to the ferric $\left(\mathrm{Fe}^{3+}\right)$ form. The ferric form of hemoglobin, methemoglobin (MetHb), renders the molecule incapable of transporting oxygen to the tissues (Morris et al., 1958). The resulting condition, methemoglobinemia, is a state of general anoxia, which in mild cases may depress animal performance but in severe cases may be fatal (Ozmen et al., 2005).

Careful stepwise introduction of nitrate in the diet of sheep allows the rumen microflora to adapt and increase their capacity to reduce both nitrate and nitrite (Alaboudi and Jones, 1985). Sheep gradually adapted over a period of $10 \mathrm{wk}$ to high nitrate diets $(1.5 \mathrm{~g}$ of nitrate/kg of BW per day) exhibited no clinical signs of methemoglobinemia (Alaboudi and Jones, 1985). In some anaerobic environments, hydrogen sulfide appears to play a role as electron donor in the reduction of nitrite to ammonia by nitrate-reducing, sulfide-oxidizing bacteria (Hubert and Voordouw, 2007). Supplementation of the diet with sulfur (Leng, 2008) or cysteine (Takahashi et al., 1998) may therefore reduce nitrite accumulation in the rumen. Sulfate is a reductant $\left(\Delta \mathrm{G}_{0}\right.$ $=-21.1 \mathrm{~kJ} / \mathrm{mol}$ of hydrogen; Ungerfeld and Kohn, 2006) and will also compete for electrons and may lower methane production.

In the current experiment, the methane-lowering potential of dietary nitrate and sulfate was evaluated after gradual introduction of these compounds to the maximum levels over a 4 -wk adaptation period. Our hypothesis is that addition of nitrate to a diet for sheep would reduce methane emissions from enteric fermentation and that an additional sulfate source would prevent methemoglobinemia and provide an additional decrease of methane emission.

\section{MATERIALS AND METHODS}

\section{Experimental Design}

The experimental design was a $2 \times 2$ factorial, with dietary nitrate and sulfate concentration as the independent factors. At the start of the experiment, 20 sheep were blocked by weight (5 blocks of 4 sheep) and allocated randomly within a block to 1 of the 4 dietary treatments. Treatments consisted of a control treatment (no addition of nitrate or sulfate), a nitrate treatment (inclusion of $2.6 \%$ nitrate in dietary DM), a sulfate treatment (inclusion of $2.6 \%$ sulfate in dietary $\mathrm{DM})$, and a treatment including both molecules in the diet (2.6\% nitrate and $2.6 \%$ sulfate).

\section{Animals and Housing}

The experiment was approved by the Institutional Animal Care and Use Committee of the Animal Sciences Group, WUR, Lelystad, the Netherlands. The experiment was conducted with 20 male crossbred Texel lambs, with initial BW of $42.9 \pm 4.3 \mathrm{~kg}$ (mean $\pm \mathrm{SD}$ ).

During a 4 -wk period of adaptation to the dietary additives, animals were housed in individual calf hutches $(195 \times 150 \times 145 \mathrm{~cm})$ to allow individual feeding. This adaptation period served to gradually acclimate the animals to the levels of nitrate and sulfate in their diet to allow the rumen microflora and fauna to adapt. During the adaptation period, formaldehyde-treated soybean meal was replaced by the experimental concentrates in weekly increments of $25 \%$. Sheep were weighed weekly during the entire experiment. 
Table 1. Feed ingredient composition of experimental rations ( $\mathrm{g} / \mathrm{kg}$ of $\mathrm{DM})$ fed to growing male lambs

\begin{tabular}{|c|c|c|c|c|}
\hline \multirow[b]{2}{*}{ Item } & \multicolumn{2}{|c|}{$-\mathrm{NO}_{3}$} & \multicolumn{2}{|c|}{$+\mathrm{NO}_{3}$} \\
\hline & $-\mathrm{SO}_{4}$ & $+\mathrm{SO}_{4}$ & $-\mathrm{SO}_{4}$ & $+\mathrm{SO}_{4}$ \\
\hline Basal diet ${ }^{1}$ & 90.0 & 90.0 & 90.0 & 90.0 \\
\hline \multicolumn{5}{|l|}{ Concentrate } \\
\hline Formaldehyde-treated soybean meal & 2.2 & 2.2 & 2.3 & 2.3 \\
\hline Urea & 1.5 & 1.5 & & \\
\hline Nitrate source $^{2}$ & & & 3.4 & 3.4 \\
\hline $\mathrm{MgSO}_{4}$ (anhydrous) & & 3.3 & & 3.5 \\
\hline $\mathrm{MgO}$ & 1.3 & & 1.4 & \\
\hline Limestone & 2.2 & 2.2 & & \\
\hline Wood cellulose & 2.8 & 0.8 & 2.9 & 0.8 \\
\hline
\end{tabular}

Following the adaptation period, 4 animals (one block) were housed individually in respiration chambers for 1 wk to determine gaseous exchanges. A new block of sheep was introduced to the chambers each week. Sheep remained housed in the calf hutches until they were transported to the respiration chambers. The first block had been fed additional nitrate and sulfate for 4 wk (the adaptation phase), whereas the last block had received the dietary additives for $8 \mathrm{wk}$ before measurement of gaseous exchange. The data on the adaptation period involve the first $4 \mathrm{wk}$ of the experiment, whereas the data on the experimental period involve the periods in the respiration chambers.

The indirect calorimetry respiration chambers used were described in detail by Verstegen et al. (1987). Temperature was maintained at $15^{\circ} \mathrm{C}$ and relative humidity at $70 \%$. Two types of chambers (length $\times$ width $\times$ height: $100 \times 80 \times 97 \mathrm{~cm}, 2$ chambers, and $100 \times$ $150 \times 200 \mathrm{~cm}, 2$ chambers, respectively) were used. Sheep were allocated to the type of chamber in such a way that each treatment was repeated 2 or 3 times within one type of chamber. Ventilation rate was $70 \mathrm{~L} /$ min for the smaller type of chambers and $90 \mathrm{~L} / \mathrm{min}$ for the other type. Consumption of oxygen and production of carbon dioxide and methane were determined per chamber in 9-min intervals as described by Verstegen et al. (1987).

\section{Feeding}

The complete ration consisted of a basal diet and a concentrate in meal form that contained the dietary additives (90 and 10\% respectively, DM basis; Table $1)$. The concentrate and basal diet were hand-mixed daily before feeding. Water was freely available during the experiment. Samples $( \pm 500 \mathrm{~g})$ of the concentrates and roughages fed were collected on $\mathrm{d} 4$ of each measurement week in the respiration chambers. After the experiment, samples were stored frozen at $-20^{\circ} \mathrm{C}$ pending further analyses.

Lambs were given their ration once daily at $0800 \mathrm{~h}$. Before each morning feeding, orts were removed from the feed bins and weighed to determine feed intake. During the adaptation period, feed was available ad libitum. During the measurement week in the respiration chambers, feed availability was restricted to allow comparison of the effects of dietary treatments on methane production without the potential confounding effect of feed intake differences. Feed availability was restricted to $95 \%$ of the feed consumed by the animal consuming the least feed within a block in the week before housing animals in the respiration chambers.

Control and nitrate containing diets were designed to be isonitrogenous by the substitution of nitrate for urea. Limestone, $\mathrm{MgO}$, and wood cellulose were used to ensure equal $\mathrm{Ca}, \mathrm{Mg}$, and $\mathrm{DM}$ concentrations among mixtures.

\section{Analyses in Feed}

Feed samples were thawed and ground over a 1-mm screen before analysis. Dry matter content was determined by drying for $16 \mathrm{~h}$ at $70^{\circ} \mathrm{C}$ in a forced-air oven. Nitrogen content was determined according to the Dumas method (ISO 16634-1; ISO, 2008). Crude protein content was calculated by multiplying total $\mathrm{N}$ content by 6.25 . Crude fat content was determined by ether extraction according to (ISO 6492; ISO, 1999). Sugar content was determined by ethanol (40\% vol/ vol) extraction and subsequent titrimetric determination of reducing sugars (as glucose) according to the Luff-Schoorl method (NEN 3571; NEN, 1974). The method of Ewers (ISO 6493: ISO, 2000) was used for determination of starch content. Neutral detergent fiber was determined according to Van Soest et al. (1991) after pretreatment with amylase. The NDF contents 
reported include residual ash. For nitrate and sulfate analysis, 2.5-g samples were extracted for $30 \mathrm{~min}$ in 200 $\mathrm{mL}$ of distilled water. The solution was filtered twice (0.45- $\mu \mathrm{m}$ filter paper), and $5 \mathrm{~mL}$ of the filtrate was used for determination of nitrate and sulfate contents by ion chromatography (DX120 ionchromatograph, Dionex, Sunnyvale, CA).

\section{Blood and Rumen Fluid Sampling}

Blood was sampled during the adaptation period at d $2,8,15,22$, and 28 at 1,3 , and $5 \mathrm{~h}$ postfeeding. Days $2,8,15$, and 22 were $1 \mathrm{~d}$ after the nitrate or sulfate was incrementally (25\%) increased in the diet. On d 28 , lambs had been on $100 \%$ of the dietary treatments for 1 wk. Blood samples were taken from the jugular vein in heparinized collection tubes (Vacutainers, Becton Dickinson, Breda, the Netherlands) and stored at $4^{\circ} \mathrm{C}$ immediately after sampling. At the end of the sampling day, samples were dispatched for analyses and were analyzed the next day. The MetHb content of the blood was determined according to the methods described in Evelyn and Malloy (1938).

After completion of the sampling period in the respiration chambers, each block of sheep was transported to a slaughterhouse $(20 \mathrm{~km})$ and rumen fluid samples $(200$ $\mathrm{mL}$ ) were taken within $1 \mathrm{~h}$ after slaughter (approximately $0900 \mathrm{~h}$; some $24 \mathrm{~h}$ following their last feed). Rumen contents were squeezed manually to obtain the rumen fluid samples. The rumen fluid samples also contained small particles. Flasks containing rumen fluid samples were immediately immersed in a bucket of ice water to stop microbial fermentation and, once all samples had been taken, stored at $-20^{\circ} \mathrm{C}$ until analysis.

\section{Determination of VFA Concentration and Microbial Composition}

Rumen fluid samples were thawed and centrifuged at $3,000 \times g$ for $10 \mathrm{~min}$. Volatile fatty acids [acetate, propionate, butyrate, valerate, and branched chain fatty acids (BCVFA)] were analyzed from the supernatant by GC using pivalic acid as an internal standard method as described previously (Holben et al., 2002). The group of BCVFA included isobutyric acid, 2-methyl-butyric acid, and isovaleric acid.

Microbes in the rumen fluid subsamples were analyzed for eubacteria, methanogens, sulfate-reducing bacteria, and protozoa. For this analysis, samples were subjected to quantitative bacterial lysis and DNA purification as described for chicken cecal samples (Apajalahti et al., 1998). Quantitative real-time PCR (qPCR) and the primers specific to eubacteria, methanogens, sulfatereducing bacteria, and protozoa were used for the quantitative analysis as described previously (Nadkarni et al., 2002; Sylvester et al., 2004; Cadillo-Quiroz et al., 2006).

\section{Calculations and Statistical Analysis}

Heat production rates were calculated from gaseous exchange (Brouwer, 1965). Gas exchange and feed intake data, averaged over the last 4 complete 24 -h periods of each period, were included in the statistical analyses.

Feed intake, daily gas exchange data, bacterial and protozoal numbers in rumen fluid, and VFA concentrations were analyzed using the MIXED procedure in SAS (2003; SAS Institute Inc., Cary, NC), with intake of nitrate and sulfate and their interaction as well as block included as fixed effects. Chamber type was included as a random effect. Homogeneity of variance of studentized model residuals was checked before the statistical analysis. Data on bacterial and protozoal numbers in rumen fluid were log-transformed before statistical analysis. For all analyses, significance was declared at $P=0.05$, and a trend was declared at $P=$ 0.10 .

Hourly gas exchange rates, (Figures 1 and 2: expressed per $\mathrm{kg}^{0.75}$ per day) were analyzed by repeated measures ANOVA, using the MIXED procedure in SAS. Intake of nitrate and sulfate and their interaction, as well as block were included as fixed effects. Effects of time and interactions between the fixed treatment effects and time were included taking hourly data obtained from the same sheep as repeated measures, applying firstorder autoregressive procedures.

\section{RESULTS}

\section{Feed Composition}

The nitrate and sulfate concentrations in the experimental concentrates were established as formulated (Table 2). In practice, minor differences existed in CP content of the concentrates, but these were only included at $10 \%$ of dietary DM, resulting in small differences in the $\mathrm{CP}$ content of the total diets. The maximum difference in $\mathrm{CP}$ content of the total diet was $7 \mathrm{~g}$ of $\mathrm{CP} / \mathrm{kg}$ of DM. The inclusion of wood cellulose led to a marked increase of NDF in concentrates without supplements and with added nitrate only.

\section{Methemoglobin in Blood During the Adaptation Period}

During supplementation of the diet with 25 or $50 \%$ of the final concentrate inclusion rate, none of the sheep had detectable blood MetHb concentrations $(<2 \%$ of 
Table 2. Analyzed chemical composition ( $\mathrm{g} / \mathrm{kg}$ of DM, unless stated otherwise) of feed ingredients and calculated chemical composition of experimental diets ${ }^{1}$

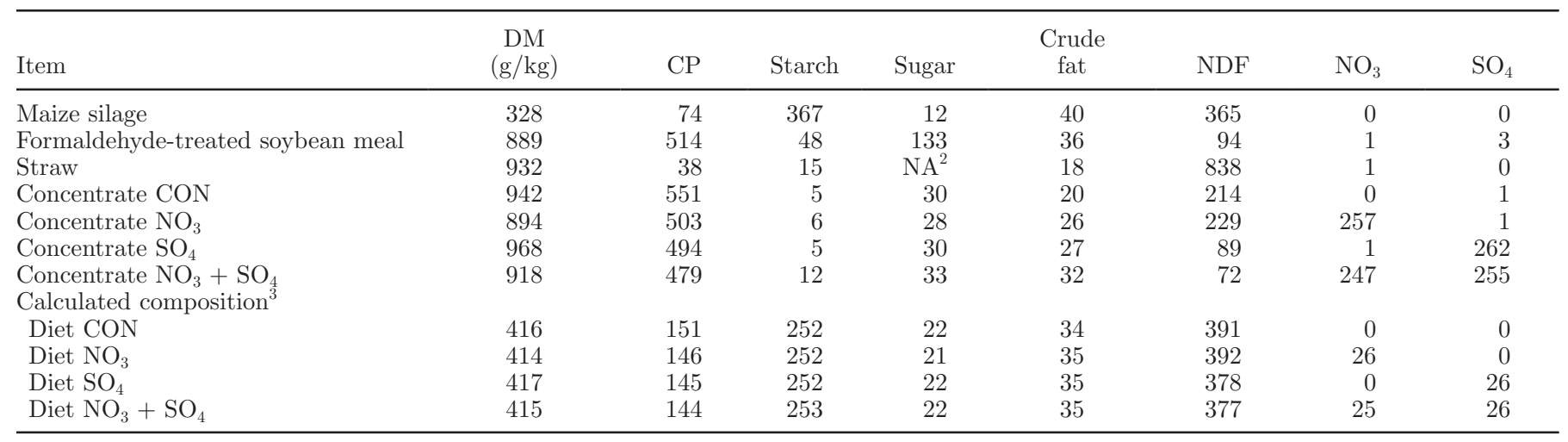

${ }^{1}$ Treatments consisted of a control treatment ( $\mathrm{CON}$, no addition of nitrate or sulfate), a nitrate treatment $\left(\mathrm{NO}_{3}\right.$, inclusion of $2.6 \%$ nitrate in dietary $\mathrm{DM})$, a sulfate treatment $\left(\mathrm{SO}_{4}\right.$, inclusion of $2.6 \%$ sulfate in dietary $\left.\mathrm{DM}\right)$, and a treatment including both molecules in the diet $\left(\mathrm{NO}_{3}+\right.$ $\mathrm{SO}_{4}, 2.6 \%$ nitrate and $2.6 \%$ sulfate).

${ }^{2}$ Not analyzed.

${ }^{3}$ Calculated chemical composition of diets based on analyzed chemical composition of feed ingredients.

$\mathrm{Hb})$. At $75 \%$ of the final inclusion rate, 1 sheep on the nitrate diet tested positive ( $>2 \%$ of $\mathrm{Hb}$ ) at $3 \mathrm{~h}$ postfeeding, but the MetHb value was only $3 \%$ of $\mathrm{Hb}$. At the $100 \%$ inclusion rate, 2 sheep on the nitrate treatment tested positive with MetHb values of 7 and $3 \%$ of $\mathrm{Hb}$, respectively, at $3 \mathrm{~h}$ postfeeding after having been fed 26 $\mathrm{g}$ of nitrate $/ \mathrm{kg}$ of DM for 1 wk (d 28). Blood samples of sheep on the control diet and both sulfate-containing diets were below detectable levels of MetHb.

\section{Feed Intake and BW Gain During the Adaptation to Dietary Nitrate and Sulfate}

During the 4-wk adaptation period, no difference in average ad libitum feed intake (average $1.1 \mathrm{~kg} \mathrm{DM} / \mathrm{d}$ ) was observed between any of the treatments. Body weight gain (average $2.75 \mathrm{~kg}$ in the adaptation period) was also unaffected by treatment.

\section{Effects of Nitrate and Sulfate on Gaseous Exchange}

The restricted feeding regimen applied during the period in the respiration chambers resulted in very similar feed intake in all treatments (Table 3). Dietary nitrate and sulfate supplementation reduced methane production $(\mathrm{L} / \mathrm{d})$ by $32 \%(P<0.001)$ and $16 \%(P=0.033)$ relative to the control treatment, respectively. No interaction was observed, indicating additivity of these effects. Nitrate addition reduced oxygen consumption by $7 \%(P=0.008)$ and carbon dioxide production by $6 \%(P=0.011)$, resulting in a reduction of the calculated heat production by $7 \%(P=0.010)$ relative to the control treatment.
The addition of sulfate to the diet tended to increase oxygen consumption $(+3 \% ; P=0.057)$ and carbon dioxide production $(+3 \%$; $P=0.050)$, resulting in a higher calculated heat production $(+3 \% ; P=0.048)$ for the sulfate-fed sheep relative to the control treatment. No interaction of nitrate and sulfate intake on heat production was observed and thus heat production was not affected by the nitrate + sulfate treatment.

\section{Diurnal Pattern of Methane Production}

The diurnal pattern of enteric methane production is presented in Figure 1. Animals were fed at 0800 h, after which methane production from animals on the control treatment progressively increased to reach a maximum at 5 to $6 \mathrm{~h}$ after feeding followed by a gradual decline. The addition of nitrate to the ration invoked a markedly different methane production pattern. Immediately after feeding, methane production rate remained at a much lower level. Twelve hours after feeding, methane production rates returned to a level similar to that of the control animals.

The methane-suppressing effect of sulfate occurred during a different period within the 24-h timeframe than that of nitrate. The largest reduction in methane production became recognizable at $10 \mathrm{~h}$ postfeeding. Interactions between nitrate and sulfate intake on methane production were not significant at any point within the $24-\mathrm{h}$ period.

\section{Diurnal Pattern of Heat Production}

Heat production was lowered by nitrate feeding, mostly in the period directly after feeding (Figure 2), 
Table 3. Dry matter intake, gaseous exchange, and heat production of growing male lambs fed nitrate and sulfate sources ${ }^{1}$

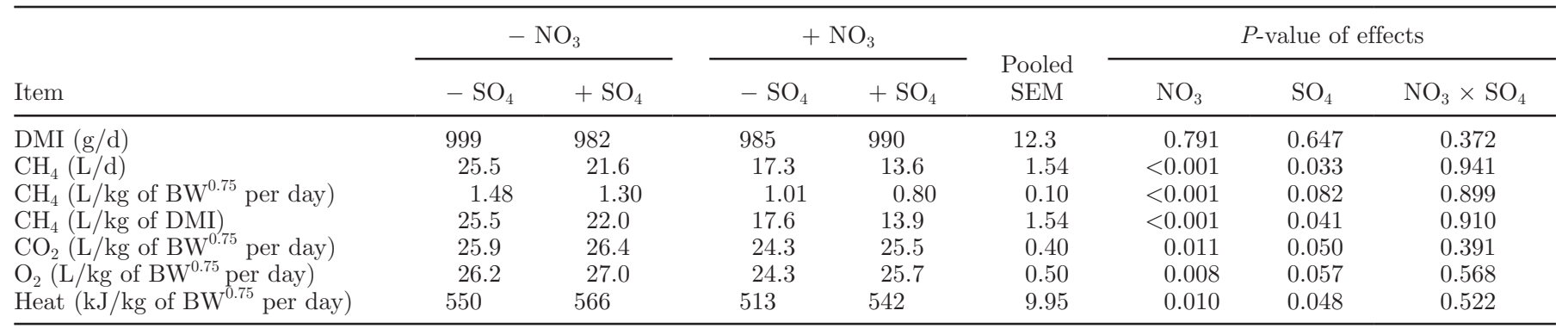

${ }^{1} \mathrm{NO}_{3}=$ nitrate added to the diet $(26 \mathrm{~g}$ of nitrate $/ \mathrm{kg}) ; \mathrm{SO}_{4}=$ sulfate added to the diet $(26 \mathrm{~g}$ of sulfate $/ \mathrm{kg})$; + or - indicate whether the component was added or not to the respective treatment.

coinciding with the period in which methane production was reduced in this treatment. Sulfate feeding increased heat production, mostly in the period directly after feeding. This resulted in equal rates of heat production between the combined nitrate and sulfate treatment and the treatment without nitrate and sulfate supplement.

\section{Ruminal VFA Concentration and Microbial Composition}

Concentrations of VFA in ruminal fluid of lambs on all treatments were not influenced by feeding nitrate or sulfate (Table 4). Proportions of BCVFA were reduced because of nitrate feeding $(P=0.036)$, but increased with sulfate feeding $(P=0.015)$.

Supplementation with sulfate increased the total number of rumen bacteria in rumen fluid $(P=0.039)$. The number of methanogens decreased when nitrate was included in the $\operatorname{diet}(P<0.001)$, whereas addition of sulfate tended to increase their numbers $(P=0.071)$. The protozoa population was unaffected by inclusion of nitrate and sulfate in the feed. Sulfate supplementation significantly increased the number of sulfate-reducing bacteria in the rumen $(P<0.001)$. The increase in sulfate-reducing bacteria tended to be larger when sulfate was added to nitrate containing diets (trend for a nitrate $\times$ sulfate interaction; $P=0.084$ ).

\section{DISCUSSION}

\section{Dietary Adaptation and Occurrence of Methemoglobinemia}

High doses of nitrate in ruminant diets have been reported to cause methemoglobinemia, decreasing the capacity of blood to transport oxygen to an animal's tissues (Bradley et al., 1939; Lewis, 1951). Clinical toxicity signs are known to occur at MetHb levels of 30 to $40 \%$ of $\mathrm{Hb}$ and higher (Bruning-Fann and Kaneene, 1993). In this experiment, blood was sampled regularly, and only slightly elevated MetHb levels were found in 2 sheep (maximum level was $7 \%$ of $\mathrm{Hb}$ for 1 sheep). Sar et al. (2004) observed MetHb levels of $18.4 \%$ of $\mathrm{Hb}$ when $0.9 \mathrm{~g}$ of nitrate $/ \mathrm{kg}$ of $\mathrm{BW}^{0.75}$ per day was administered intraruminally to sheep in a single load. In another study, Takahashi et al. (1998) pulse-dosed $\mathrm{NaNO}_{3}$ into

Table 4. Total VFA concentrations, VFA molar proportions, and microbial composition $(\mathrm{log} / \mathrm{mL}$ of rumen contents) in rumen contents of growing male lambs fed nitrate and sulfate sources ${ }^{1}$

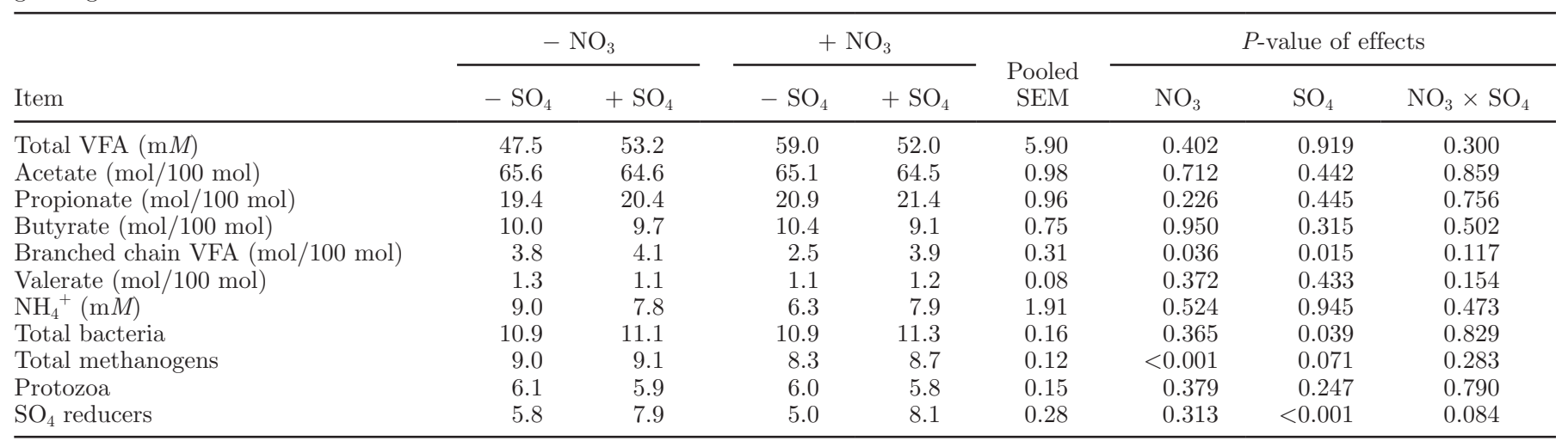

${ }^{1} \mathrm{NO}_{3}=$ nitrate added to the diet $(26 \mathrm{~g}$ of nitrate $/ \mathrm{kg}) ; \mathrm{SO}_{4}=$ sulfate added to the diet $(26 \mathrm{~g}$ of sulfate $/ \mathrm{kg}) ;+$ or - indicate whether the component was added or not to the respective treatment. 


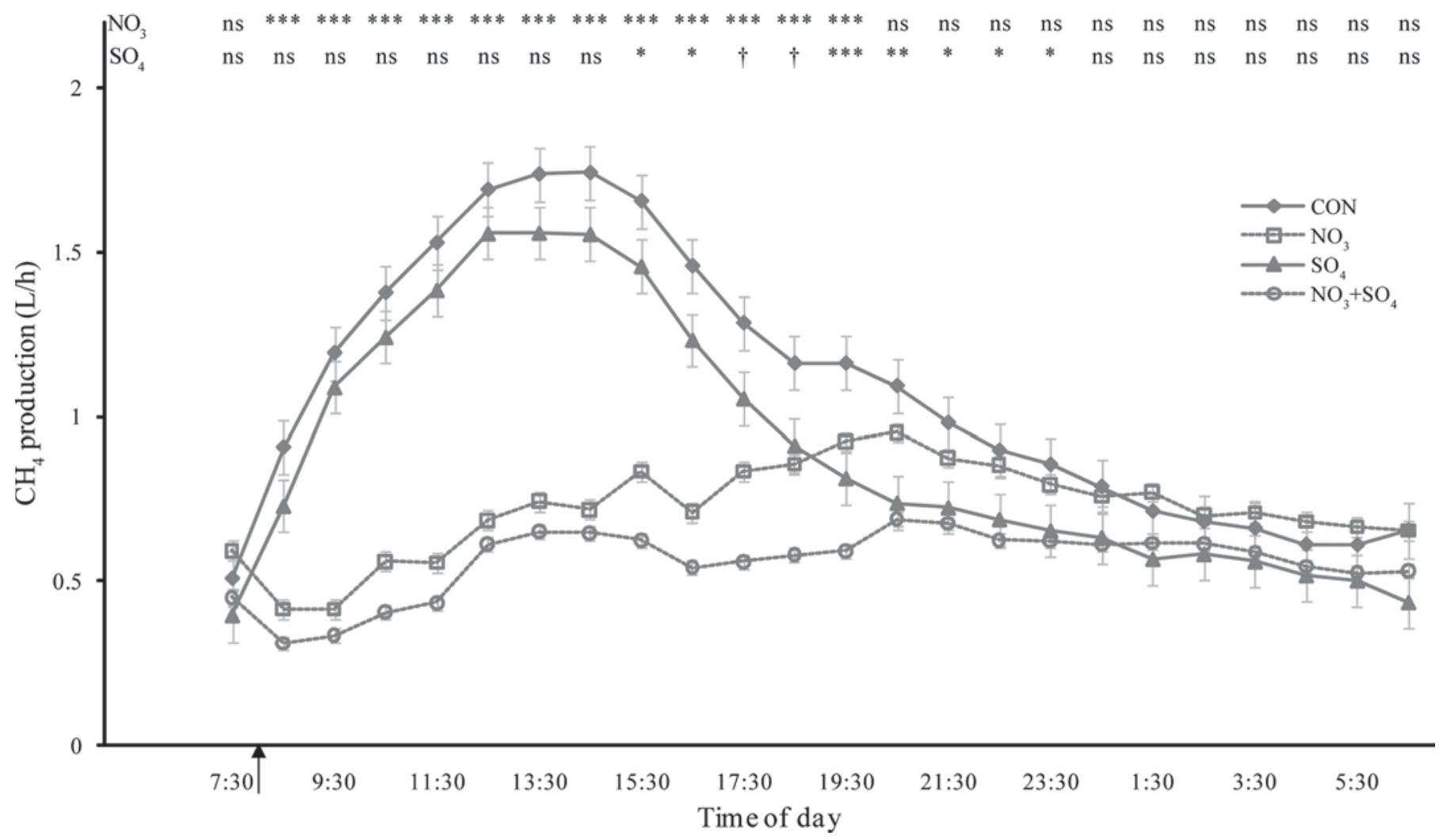

Figure 1. Diurnal methane production pattern (L/d) of male lambs fed nitrate and sulfate. Error bars indicate SEM. Symbols indicate significance of main effects of $\mathrm{NO}_{3}$ or $\mathrm{SO}_{4}$ and their interaction $\left(\dagger P<0.10 ;{ }^{*} P<0.05\right.$; ${ }^{* *} P<0.01$; $\left.{ }^{* * *} P<0.001\right)$. Arrow indicates time of feeding. Treatments consisted of a control treatment $\left(\mathrm{CON}\right.$, no addition of nitrate or sulfate), a nitrate treatment $\left(\mathrm{NO}_{3}\right.$, inclusion of $2.6 \%$ nitrate in dietary $\mathrm{DM})$, a sulfate treatment $\left(\mathrm{SO}_{4}\right.$, inclusion of $2.6 \%$ sulfate in dietary $\left.\mathrm{DM}\right)$, and a treatment including both molecules in the diet $\left(\mathrm{NO}_{3}\right.$ $+\mathrm{SO}_{4}, 2.6 \%$ nitrate and $2.6 \%$ sulfate).

the rumen of sheep at a rate of $1.1 \mathrm{~g}$ of nitrate $/ \mathrm{kg}$ of $\mathrm{BW}^{0.75}$ per day and observed MetHb levels of over $30 \%$ of $\mathrm{Hb}$. Although considerably more nitrate (1.6 g of nitrate $/ \mathrm{kg}$ of $\mathrm{BW}^{0.75}$ per day) was provided in our study, lower levels of methemoglobin were observed. The difference in observed MetHb values between our study and the experiments of Sar et al. (2004) and Takahashi et al. (1998) may originate in the method of application to the animal; in our study the nitrate was fed, whereas in the other studies the nitrate was pulse-dosed into the rumen. This pulse-dosing would presumably cause much higher peak values of nitrite in rumen fluid, providing a possible explanation for the higher MetHb values observed in the other studies. Another possible explanation could be that in both other studies sheep were not adapted to nitrate and the rumen microflora possibly had a lower capacity to reduce nitrite than rumen microflora of the sheep in our experiment.

Allison and Reddy (1984) demonstrated that nitrite reduction rates can be increased from $25 \mathrm{nmol} / \mathrm{min}$ per $\mathrm{mL}$ of rumen fluid to $62 \mathrm{nmol} / \mathrm{min}$ per $\mathrm{mL}$ by feeding nitrate $(0.47 \mathrm{~g}$ of nitrate $/ \mathrm{kg}$ of $\mathrm{BW}$ per day) to sheep, whereas nitrate reduction rates were increased 26-fold (from 4.5 to $117 \mathrm{nmol} / \mathrm{min}$ per $\mathrm{mL}$ ) compared with sheep fed no additional nitrate in their diets. A similar finding was reported by Alaboudi and Jones (1985) when sheep were slowly introduced to high nitrate diets (1.5 g of nitrate $/ \mathrm{kg}$ of BW per day). Nitrate concentrations higher than $0.5 \%$ of DM in forages can be lethal for unadapted ruminants (Bruning-Fann and Kaneene, 1993), but adaptation apparently enabled rumen bacteria to increase in numbers or increase their nitrite-reducing capacity. Methemoglobin was not detected (detection limit 2\% MetHb) in animals on the control treatment and treatments receiving additional sulfate. This indicates that sulfate may play a role in the acceleration of nitrite reduction in the rumen or remove a metabolic restriction to the production of ammonia from nitrite when diets contain high levels of nitrate. The time elapsed between sampling of the blood and the actual analysis for methemoglobin was approximately $24 \mathrm{~h}$. Fukui et al. (1980) reported that $36.1 \%$ of the original amount of MetHb was recovered after $24 \mathrm{~h}$ storage in a refrigerator, and Sleight and 


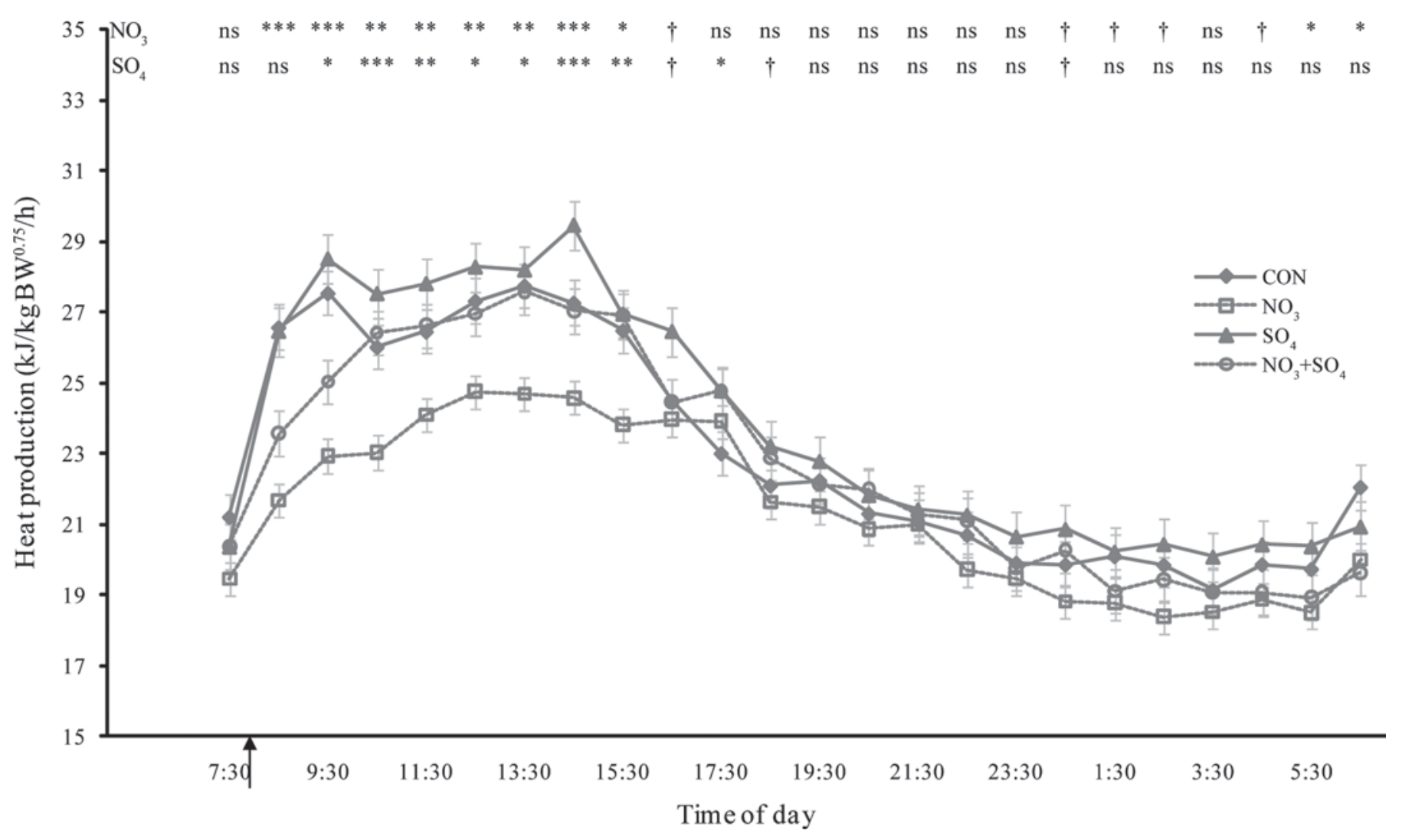

Figure 2. Diurnal pattern of heat production $\left(\mathrm{kJ} / \mathrm{g}\right.$ of $\mathrm{BW} \mathrm{W}^{0.75}$ per day) of male lambs fed nitrate and sulfate. Error bars indicate SEM. Symbols indicate significance of main effects of $\mathrm{NO}_{3}$ or $\mathrm{SO}_{4}$ and their interaction $\left(\dagger P<0.10 ; * P<0.05 ;{ }^{* *} P<0.01\right.$; $\left.{ }^{* * *} P<0.001\right)$. Arrow indicates time of feeding. Treatments consisted of a control treatment $\left(\mathrm{CON}\right.$, no addition of nitrate or sulfate), a nitrate treatment $\left(\mathrm{NO}_{3}\right.$, inclusion of $2.6 \%$ nitrate in dietary DM), a sulfate treatment $\left(\mathrm{SO}_{4}\right.$, inclusion of $2.6 \%$ sulfate in dietary DM), and a treatment including both molecules in the diet $\left(\mathrm{NO}_{3}+\mathrm{SO}_{4}, 2.6 \%\right.$ nitrate and $2.6 \%$ sulfate $)$.

Sinha (1968) reported reductions of over $50 \%$ in MetHb when guinea pig blood was stored for a 24 -h period in refrigerated conditions. The MetHb values reported here may not, therefore, represent the actual values at the time of sampling. However, no clinical signs of methemoglobinemia were observed during the experiment. Earlier reports also mentioned no clinical signs of methemoglobinemia when sheep were fed high doses of nitrate in their diets (Carver and Pfander, 1974; Alaboudi and Jones, 1985).

\section{Feed Intake and BW Gain}

Feed intake of lambs in the adaptation period was not different among treatments. However, the small sample size of animals used in this study does not allow firm conclusions to be drawn concerning effects on feed intake. Bruning-Fann and Kaneene (1993) reported negative effects on feed intake in sheep when dietary nitrate exceeded $3 \%$ of DM. This reduction in feed intake may be related to a nitrite-induced depression of forage cell wall digestion as demonstrated in vitro by
Marais et al. (1988). To avoid a possible reduction in DMI, sheep were fed restrictedly when in the respiration chambers.

\section{Nitrate and Sulfate as Hydrogen Sinks}

The inhibition of methane production by nitrate is most likely attributable to the energetically more favorable use of hydrogen in the reduction of nitrate to ammonia. This implies that 4 moles of hydrogen are redirected toward nitrate reduction, thereby theoretically lowering methane production by 1 mole for each mole of nitrate reduced, which is equivalent to a reduction of methane emission by $25.8 \mathrm{~g}$ for each $100 \mathrm{~g}$ of nitrate fed.

Sheep given nitrate in their diet consumed, on average, $25.2 \mathrm{~g}$ of nitrate/d during methane measurements, which would theoretically lower methane production by $6.5 \mathrm{~g} / \mathrm{d}$. The actual decrease in methane production for the nitrate treatment was $5.8 \mathrm{~g} / \mathrm{d}$. Thus, the decrease in methane production was $89 \%$ of the quantity that could be explained by stoichiometry, indicating that 
most of the nitrate fed was reduced in the rumen. The nitrate source used in this study was highly soluble and available in the rumen. Lewis (1951) found that approximately $8 \%$ of a nitrate load suddenly introduced directly into the rumen was recovered in urine. Irreversible loss of nitrate in urine may be responsible for the lower than predicted methane reduction in this study.

The addition of sulfate to the diet led to a reduction of $16 \%$ in daily methane production. Sulfate reduction to hydrogen sulfide also consumes 8 electrons and thus offers the same potential per mole to decrease methane emissions as nitrate. From a thermodynamic perspective, sulfate reduction is more favorable than methanogenesis (Ungerfeld and Kohn, 2006). Stochiometrically, the full reduction of $100 \mathrm{~g}$ sulfate to hydrogen sulfide would decrease methane production by $16.7 \mathrm{~g}$. In our study, sheep on the sulfate treatment consumed on average $25.8 \mathrm{~g}$ sulfate/d, which would correspond to a methane decrease of $4.3 \mathrm{~g} / \mathrm{d}$ if it were all converted to $\mathrm{H}_{2} \mathrm{~S}$. The actual observed decrease in methane was 2.9 $\mathrm{g} / \mathrm{d}$, which is $67 \%$ of the stoichiometric potential.

The competition for hydrogen between sulfate reduction and methanogenesis has been studied in anaerobic digesters. Isa et al. (1986) concluded from their experiment that the extent of decrease in methane production from sulfate addition is dependent on both the sulfate concentration in the medium and the residence time within the digester. At low sulfate concentrations (0.5 $\mathrm{g}$ of sulfate/L) relatively more electrons were directed toward sulfate reduction compared with a high sulfate concentration $(5.0 \mathrm{~g}$ of sulfate/L). Increasing the residence time from 0.5 to $10 \mathrm{~d}$ in the digester also markedly increased the flow of electrons from methanogenesis toward sulfate reduction. Rumen liquid passage rate in sheep is quite high (7-8\%/h; Lopez et al., 2003), which might offer an explanation for the lower than expected use of hydrogen for sulfate reduction.

Sheep on sulfate treatments were fed a considerable amount of $\mathrm{S}$ in the $\operatorname{diet}(8.5 \mathrm{~g}$ of $\mathrm{S} / \mathrm{kg}$ of $\mathrm{DM})$. This level was chosen for 2 reasons: 1 ) to be able to quantify the contribution of sulfate reduction to reduce methane emissions, and 2) in an attempt to prevent nitrite accumulation and, therefore, problems associated with methemoglobinemia. The sulfate inclusion rate was, however, well above the maximum recommendations indicated by NRC (4 $\mathrm{g}$ of $\mathrm{S} / \mathrm{kg}$ of DM; NRC, 2001). Feeding above this upper limit on more traditional diets increases the risk of polioencephalomalacia, caused by high levels of hydrogen sulfide in the rumen headspace and the subsequent inhalation of hydrogen sulfide (Gould, 1998). Results from this experiment do, however, show that sulfate is effective in decreasing methane production. No clinical signs of polioencephalomalacia were observed during the experiment.

\section{Effects of Nitrate and Sulfate on Oxygen Consumption and Carbon Dioxide and Heat Production}

Oxygen consumption, carbon dioxide production, and the resulting heat production were all lower in sheep consuming nitrate. Sheep on all treatments consumed the same amount of feed and gross energy during the heat production measurements. Therefore, the reduced heat production of the nitrate fed sheep results from a reduced metabolizability of the ingested gross energy, from a reduced conversion of ME into heat, potentially resulting in an increase in energy retention, or from a combination of the two. Because ME intake was not measured in this study, the distinction cannot be made. However, arguments for both options can be made.

It has been documented that accumulation of nitrite in rumen fluid reduces cell wall fermentation in vitro (Marais et al., 1988) and would therefore potentially reduce energy digestibility. In addition, reduced cell wall fermentability may explain the lower level of methanogenesis observed in this experiment for the nitrate treatment. As discussed previously, occurrence of methemoglobinemia could not fully be excluded in this study, and this may provide an explanation for a reduced conversion of ME into heat.

As concluded by Takahashi et al. (1998), oxygen consumption decreases by $1 \%$ for each $10 \%$ increase in methemoglobin. This would imply that in our study, methemoglobin would have been $6 \%$ of $\mathrm{Hb}$ in the nitrate-fed sheep and this may have gone undetected because of the time elapsed between sampling and analysis. On the other hand, potential depression of rumen digestion was not quantified in the study of Takahashi et al.(1998), nor in a subsequent study by Sar et al. (2005), and the reduction in oxygen consumption observed in these studies may, in part, be caused by a reduction in ME intake.

Surprisingly, sulfate feeding increased heat production. The $\mathrm{S}$ content in the control and nitrate diets was designed to be $1.2 \mathrm{~g}$ of $\mathrm{S} / \mathrm{kg}$ of $\mathrm{DM}$, which is below recommendations (NRC, 2001). Moreover, most of the dietary $\mathrm{S}$ was included in the formaldehyde-treated soybean meal, which probably resulted in a low rumen availability of S. Addition of S sources to S-deficient diets stimulates the total number of bacteria and stimulates rumen fermentation and microbial protein synthesis (Hegarty et al., 1994). Therefore, rumen fermentation may have been stimulated by the additional 
$\mathrm{S}$ from sulfate in the diet, resulting in increased ME intake and a concomitant increase in heat production.

\section{Effects of Nitrate and Sulfate on Ruminal Fermentation and Microbial Populations}

The thermodynamically favorable reduction of nitrate preferentially directs hydrogen away from methanogenesis, but could also draw hydrogen away from other processes such as propionogenesis. Farra and Satter (1971) observed a shift in the VFA profile from propionate to acetate when diets high in nitrate were fed to dairy cows. The butyrate concentration was also significantly reduced. The same phenomenon was observed by Allison and Reddy (1984) when sheep were fed nitrates. No differences in concentrations of these VFA were observed in the present study. A major difference between the current experiment and that of Farra and Satter (1971) is the time of rumen fluid sampling. Farra and Satter (1971), using fistulated cows, sampled $1 \mathrm{~h}$ after feeding, whereas our samples were obtained approximately 24 $\mathrm{h}$ after feeding. The methane-lowering effect was only apparent in the 12-h period after feeding (Figure 1) and the same may be true for any effects on VFA production, because both are dependent on the competition for hydrogen in nitrate reduction. In sheep, a shift in VFA proportions from butyrate to acetate was reported when nitrate was included in the diet (Alaboudi and Jones, 1985). However, this shift was only observed up to $1.5 \mathrm{~h}$ after feeding. The addition of nitrate to the diets invoked a decrease in the proportion of BCVFA in this experiment. This may reflect a lower level of dietary proteolysis or reduced microbial lysis on this treatment. Rumen fluid of sheep with added sulfate in their diet contained a higher proportion of BCVFA, which may be related to the higher microbial activity on this treatment.

Dietary addition of nitrate decreased the number of methanogens in the rumen fluid of these sheep, which may be attributed to a lower electron pool available to the methanogens or to the toxicity of the intermediately formed nitrite during nitrate reduction (Allison et al., 1981). Methanogens are dependent on hydrogen availability, and depletion of hydrogen through uptake by nitrate-reducing bacteria may explain the declining population density of methanogens. The lower number of methanogens observed on the nitrate treatment might be an alternative explanation for the reduced methane production observed for this treatment.

\section{CONCLUSIONS}

Adding salts of nitrate or sulfate to the diet of sheep reduced enteric methane production. Moreover, the effects of both products on methane production were additive. Provided that these substances can be fed in a safe way, they are powerful agents to reduce methane production by sheep.

\section{ACKNOWLEDGMENTS}

The authors thank Geronda Klop (student of the University of Applied Sciences HAS Den Bosch) and Rob Hulshof (student of Wageningen University) for their conscientious assistance during the implementation of the experiment. Staff of experimental facilities De Haar and Viersprong are acknowledged for their skilled technical assistance. This experiment was partially funded by SenterNovem, an agency of the Dutch Ministry of Economical Affairs.

\section{REFERENCES}

Alaboudi, A. R., and G. A. Jones. 1985. Effect of acclimation to high nitrate intakes on some rumen fermentation parameters in sheep. Can. J. Anim. Sci. 65:841-849.

Allison, M. J., and C. A. Reddy. 1984. Adaptations of gastrointestinal bacteria in response to changes in dietary oxalate and nitrate. Pages 248-256 in Third International Symposium on Microbial Ecology, Washington DC.

Allison, M. J., C. A. Reddy, and H. M. Cook. 1981. The effects of nitrate and nitrite on vfa and ch4 production by ruminal microbes. J. Anim. Sci. 53(Suppl.):283. (Abstr.)

Apajalahti, J. H. A., L. K. Sarkilahti, B. R. E. Maki, J. P. Heikkinen, P. H. Nurminen, and W. E. Holben. 1998. Effective recovery of bacterial DNA and percent-guanine-plus-cytosine-based analysis of community structure in the gastrointestinal tract of broiler chickens. Appl. Environ. Microbiol. 64:4084-4088.

Beauchemin, K. A., M. Kreuzer, F. O'Mara, and T. A. McAllister. 2008. Nutritional management for enteric methane abatement: A review. Aust. J. Exp. Agric. 48:21-27.

Beauchemin, K. A., and S. M. McGinn. 2006. Methane emissions from beef cattle: Effects of fumaric acid, essential oil, and canola oil. J. Anim. Sci. 84:1489-1496.

Bradley, W. B., O. A. Beath, and H. F. Eppson. 1939. Oat hay poisoning. Science 89:365.

Brouwer, E. 1965. Report of sub-committee on constants and factors. Pages 441-443 in Energy Metabolism. K. L. Blaxter, ed. Publication no 11. European Association for Animal Production. Academic Press, London, UK.

Bruning-Fann, C. S., and J. B. Kaneene. 1993. The effects of nitrate, nitrite, and n-nitroso compounds on animal health. Vet. Hum. Toxicol. 35:237-253.

Cadillo-Quiroz, H., S. Bräuer, E. Yashiro, C. Sun, J. Yavitt, and S. Zinder. 2006. Vertical profiles of methanogenesis and methanogens in two contrasting acidic peatlands in central New York State, USA. Environ. Microbiol. 8:1428-1440.

Carver, L. A., and W. H. Pfander. 1974. Some metabolic aspects of urea and/or potassium nitrate utilization by sheep. J. Anim. Sci. 38:410-416.

Dijkstra, J., J. France, and D. R. Davies. 1998. Different mathematical approaches to estimating microbial protein supply in ruminants. J. Dairy Sci. 81:3370-3384.

Ellis, J. L., J. Dijkstra, E. Kebreab, A. Bannink, N. E. Odongo, B. W. McBride, and J. France. 2008. Aspects of rumen microbiology central to mechanistic modelling of methane production in cattle. J. Agric. Sci. 146:213-233.

Evelyn, K. A., and H. T. Malloy. 1938. Microdetermination of oxyhemoglobin, methemoglobin, and sulfhemoglobin in a single sample of blood. J. Biol. Chem. 126:655-663. 
Farra, P. A., and L. D. Satter. 1971. Manipulation of the ruminal fermentation. III. Effect of nitrate on ruminal volatile fatty acid production and milk composition. J. Dairy Sci. 54:1018-1024.

Foley, P. A., D. A. Kenny, D. K. Lovett, J. J. Callan, T. M. Boland, and F. P. O'Mara. 2009. Effect of dl-malic acid supplementation on feed intake, methane emissions, and performance of lactating dairy cows at pasture. J. Dairy Sci. 92:3258-3264.

Fukui, Y., Y. Yamamoto, and K. Matsubara. 1980. Reduction with the lapse of time of methemoglobin in blood sample. Jpn. J. Legal Med. 31:536-568.

Gould, D. H. 1998. Polioencephalomalacia. J. Anim. Sci. 76:309314

Guo, W. S., D. M. Schafer, X. X. Guo, L. P. Ren, and Q. X. Meng. 2009. Use of nitrate-nitrogen as a sole dietary nitrogen source to inhibit ruminal methanogenesis and to improve microbial nitrogen synthesis in vitro. Asian-australas. J. Anim. Sci. 22:542-549.

Hegarty, R. S., J. V. Nolan, and R. A. Leng. 1994. The effects of protozoa and of supplementation with nitrogen and sulfur on digestion and microbial metabolism in the rumen of sheep. Aust. J. Agric. Res. 45:1215-1227.

Holben, W. E., P. Williams, M. Saarinen, L. K. Sarkilahti, J. H. A. Apajalahti, and M. A. Gilbert. 2002. Phylogenetic analysis of intestinal microflora indicates a novel mycoplasma phylotype in farmed and wild salmon. Microb. Ecol. 44:175-185.

Hubert, C., and G. Voordouw. 2007. Oil field souring control by nitratereducing sulfurospirillum spp. That outcompete sulfate-reducing bacteria for organic electron donors. Appl. Environ. Microbiol. 73:2644-2652.

Immig, I. 1996. The rumen and hindgut as source of ruminant methanogenesis. Environ. Monit. Assess. 42:57-72.

Isa, Z., S. Grusenmeyer, and W. Verstraete. 1986. Sulfate reduction relative to methane production in high-rate anaerobic digestion: Microbiological aspects. Appl. Environ. Microbiol. 51:580-587.

ISO. 1999. Animal feeding stuffs - Determination of fat content. International Standards Organization, Geneva, Switzerland.

ISO. 2000. Animal feeding stuffs - Determination of starch contentpolarimetric method. International Standards Organization, Geneva, Switzerland.

ISO. 2008. Food products - Determination of the total nitrogen content by combustion according to the Dumas principle and calculation of the crude protein content-part 1: Oilseeds and animal feeding stuffs. International Organization for Standardization, Geneva, Switzerland

Joblin, K. N. 1999. Ruminal acetogens and their potential to lower ruminant methane emissions. Aust. J. Agric. Res. 50:1307-1314.

Johnson, K. A., and D. E. Johnson. 1995. Methane emissions from cattle. J. Anim. Sci. 73:2483-2492.

Le Van, T. D., J. A. Robinson, J. Ralph, R. C. Greening, W. J. Smolenski, J. A. Z. Leedle, and D. M. Schaefer. 1998. Assessment of reductive acetogenesis with indigenous ruminal bacterium populations and Acetitomaculum ruminis. Appl. Environ. Microbiol. 64:3429-3436.

Leng, R. A. 2008. The potential of feeding nitrate to reduce enteric methane production in ruminants. A report to the department of climate change. Commonwealth Government of Australia, Canberra. www.penambulbooks.com.

Leng, R. A., and J. V. Nolan. 1984. Nitrogen metabolism in the rumen. J. Dairy Sci. 67:1072-1089.

Lewis, D. 1951. The metabolism of nitrate and nitrite in the sheep; the reduction of nitrate in the rumen of the sheep. Biochem. J. 48:175-180.

Lopez, S., F. D. D. Hovell, J. Dijkstra, and J. France. 2003. Effects of volatile fatty acid supply on their absorption and on water kinetics in the rumen of sheep sustained by intragastric infusions. J. Anim. Sci. 81:2609-2616.
Marais, J. P., J. J. Therion, R. I. Mackie, A. Kistner, and C. Dennison. 1988. Effect of nitrate and its reduction products on the growth and activity of the rumen microbial population. Br. J. Nutr. 59:301-313.

Molano, G., T. W. Knight, and H. Clark. 2008. Fumaric acid supplements have no effect on methane emissions per unit of feed intake in wether lambs. Aust. J. Exp. Agric. 48:165-168.

Morris, M. P., B. Cancel, and A. Gonzalez-Mas. 1958. Toxicity of nitrates and nitrites to dairy cattle. J. Dairy Sci. 41:694-696.

Nadkarni, M. A., F. E. Martin, N. A. Jacques, and N. Hunter. 2002. Determination of bacterial load by real-time PCR using a broadrange (universal) probe and primers set. Microbiology 148:257266.

NEN. 1974. Onderzoekingsmethoden voor veevoeders-Bepaling van het gehalte aan reducerende suiker, ruwe totaal suiker, saccharose en ruwe lactose. NEN (Nederlandse Norm), Delft, the Netherlands.

NRC. 2001. Nutrient Requirements of Cattle. 7th rev. ed. National Academy Press, Washington, DC.

Ozmen, O., F. Mor, S. Sahinduran, and A. Unsal. 2005. Pathological and toxicological investigations of chronic nitrate poisoning in cattle. Toxicol. Environ. Chem. 87:99-106.

Sar, C., B. Mwenya, B. Santoso, K. Takaura, R. Morikawa, N. Isogai, Y. Asakura, Y. Toride, and J. Takahashi. 2005. Effect of Escherichia coli wild type or its derivative with high nitrite reductase activity on in vitro ruminal methanogenesis and nitrate/nitrite reduction. J. Anim. Sci. 83:644-652.

Sar, C., B. Santoso, B. Mwenya, Y. Gamo, T. Kobayashi, R. Morikawa, K. Kimura, H. Mizukoshi, and J. Takahashi. 2004. Manipulation of rumen methanogenesis by the combination of nitrate with [beta] 1-4 galacto-oligosaccharides or nisin in sheep. Anim. Feed Sci. Technol. 115:129-142.

Sleight, S. D., and D. P. Sinha. 1968. Prevention of methemoglobin reduction in blood samples. J. Am. Vet. Med. Assoc. 152:15211525

Steinfeld, H., P. Gerber, T. Wassenaar, V. Castel, M. Rosales, and C. De Haan. 2006. Livestock's long shadow. Food and Agriculture Organization of the United Nations, Rome, Italy.

Sylvester, J. T., S. K. R. Karnati, Z. Yu, M. Morrison, and J. L. Firkins. 2004. Development of an assay to quantify rumen ciliate protozoal biomass in cows using real-time PCR. J. Nutr. 134:3378-3384.

Takahashi, J., M. Ikeda, S. Matsuoka, and H. Fujita. 1998. Prophylactic effect of L-cysteine to acute and subclinical nitrate toxicity in sheep. Anim. Feed Sci. Technol. 74:273-280.

Ungerfeld, E. M., and R. A. Kohn. 2006. The role of thermodynamics in the control of ruminal fermentation. Pages 55-85 in Ruminant Physiology: Digestion, Metabolism and Impact of Nutrition on Gene Expression, Immunology and Stress K. Sejrsen, T. Hvelplund, and M. O. Nielsen, ed. Wageningen Academic Publishers, Wageningen, the Netherlands.

Van Soest, P. J., J. B. Robertson, and B. A. Lewis. 1991. Methods for dietary fiber, neutral detergent fiber, and nonstarch polysaccharides in relation to animal nutrition. J. Dairy Sci. 74:3583-3597.

Verstegen, M. W. A., W. Van der Hel, H. A. Brandsma, A. M. Henken, and A. M. Bransen. 1987. The Wageningen respiration unit for animal production research: A description of the equipment and its possibilities. Pages 21-48 in Energy Metabolism in Farm Animals: Effects of Housing, Stress and Disease. Martinus Nijhoff Publishers, Dordrecht, the Netherlands.

Wallace, R. J., T. A. Wood, A. Rowe, J. Price, D. R. Yanez, S. P. Williams, and C. J. Newbold. 2006. Encapsulated fumaric acid as a means of decreasing ruminal methane emissions. Int. Congr. Ser. 1293:148-151. 